\title{
Ecotourism as Leisure and Labor in the Experience of the "Great" Outdoors
}

\author{
Stacey K. Sowards * and Paulami Banerjee \\ Department of Communication Studies, The University of Texas at Austin, Austin, TX, United States
}

\section{OPEN ACCESS}

Edited by:

Jennifer Peeples,

Utah State University, United States

Reviewed by:

Elizabeth Brunner,

South Yuba River Citizens League,

United States

Michael Salvador

California State University, San

Bernardino, United States

Bridie McGreavy,

University of Maine, United States

*Correspondence:

Stacey K. Sowards

stacey.sowards@utexas.edu

Specialty section:

This article was submitted to

Science and Environmental

Communication,

a section of the journal

Frontiers in Communication

Received: 05 July 2021

Accepted: 25 November 2021

Published: 15 December 2021

Citation:

Sowards SK and Banerjee P (2021) Ecotourism as Leisure and Labor in the Experience of the "Great" Outdoors.

Front. Commun. 6:736762.

doi: 10.3389/fcomm.2021.736762
Ecotourism as an international concept promotes foreign and domestic tourism to locations in forests, oceans, and other forms of the natural world. National parks and other preserved ecosystems are popular destinations, usually located in the so-called developing countries or Global South countries, such as South and Southeast Asia, Central and South America, and Africa. This paper examines the construction of labor and leisure as forms of experience of the "Great" Outdoors for both ecotourists and local peoples. We argue that ecotourism is a form of colonial/racialized/gendered gaze, in which power imbalances are reflected in people's experiences of ecotourism as labor and leisure. We use case studies in Indonesia and India, based on our long standing field research in each respective country.

Keywords: ecotourism, travel and tourism, leisure, labor, colonialism in India, colonialism in Southeast Asia

\section{INTRODUCTION}

Ecotourism, or tourism that is centered around visiting natural environments and participating in activities such as national park touring and wildlife viewing, has grown in popularity with international and domestic tourists alike. While ecotourism can refer to any kind of tourism that engages with some aspect of the natural world, in practice, it often refers to tourism in so-called developing or Global South countries, where local or Indigenous people host tourists as a way to earn income and tourists enjoy cultural experiences in the "Great" Outdoors. Ecotourism has been promoted as a way for such local and/or Indigenous people to make a living while at the same time preserving interest in protecting natural habitats (e.g., see Sowards, 2010; Sowards, 2012; Sowards and Varela, 2013). While ecotourism is generally seen as a positive benefit for bringing revenue to poorer communities, the negative aspects can be significant. Revenue leakage (in which income goes to outside providers, guides, or services instead of local people), waste disposal problems, plastics and sewage issues, cultural misunderstandings, inappropriate wildlife interactions, increased human impact on soil, forests, and waterways, and lack of tourist preparation for cultural and natural world engagement are just a few of the issues that arise in communities both new to and experienced in ecotourism industries (e.g., see Honey, 1999; Weaver, 2001; Buckley, 2004; Rubita, 2012).

In this article, we explore how ecotourism is experienced as both a form of leisure and labor, often with class, caste, gender, linguistic, racial, and ethnic implications. We use three communities as case studies for understanding how people as tourists seek exoticized "Great" Outdoors experiences in India and Indonesia. First, the landlocked state of Sikkim in India, located in northeastern India bordering China, Nepal, and Bhutan, promotes ecotourism predominantly through the gateway city of Siliguri in the state of West Bengal, India. Ecotourism in Sikkim has increased rapidly since 2002, with the tourism sector accounting for nearly $7.7 \%$ of the gross state domestic product (GDP) (Government of Sikkim, 2018) and providing employment to an estimated 7 out of every 10 families 
(Sarkar, 2020). However, recent studies show that local communities have yet to reap meaningful, long-term economic benefits from this boom. While the focus has been on developing and promoting ecotourism in the state around traditional village homestays benefitting local and Indigenous communities, it is estimated that approximately $61 \%$ of the workforce in the tourism sector in Sikkim are from outside the state, resulting in revenue leakage in the local context and gradual undermining of traditional customs and practices of rural Sikkim (Whelan, 2013; Development Alternatives, 2018). We define this economic and cultural leakage as the neoliberal failings of ecotourism.

In our second case, West Bali National Park, located on the island of Bali in Indonesia, a local organization developed a micro-tourism project to increase revenue for local communities beyond the mainstream forms of tourism in other parts of Bali. The communities here are approximately a $50-50 \%$ mix of Muslims and Hindus, so religion and different ways of life are also part of promoting ecotourism as cultural experience. This project was promoted through a local nongovernmental organization and the national park office. We found deeply gendered practices, along with class inequities within the communities, which we label gendered/classed economies, even as they are also racialized/nationalized. Finally, our third case examines national parks in Kalimantan (Indonesian part of Borneo Island). These parks, Gunung Palung, Tanjung Puting, Kutai, and Kayan Mentarang, have received relatively few visitors, but such tourists can have outsized impact, due to lack of infrastructure and difficulty of travel to such locations. The appeal of orangutan tourism in some of these parks draws some international and domestic tourism, but the problems of inappropriate wildlife interaction and waste management need to be addressed. The draw of Indigenous peoples and their performances means that this case also represents the exoticization of cultures and forests. In the Indonesian case studies, communities have benefited from such tourism, but the same problems, such as revenue leakage, waste management, and environmental impact are still concerns as they are in our Indian case study.

These case studies illustrate how the dichotomy of labor/ leisure becomes amplified in ecotourism settings through relations of racialization, colonization, and gender (e.g., Crawshaw and Urry, 1997; Sowards, 2012). This essay unpacks the racialized, classed, and gendered aspects of labor in relationship to privileged forms of leisure. We look at the intersectionalities of ecotourism, globalization, neoliberalism, and regional governance to reveal how Indigenous and local ways of life are being rewritten by cultural and religious appropriation, cultural reproduction, and neoliberal conservation debates, to acknowledge and understand what is truly at stake, both locally and globally. Our case studies are based on extensive fieldwork research in Sikkim (India), Bali, and Kalimantan (Indonesia). Our field research is based on ethnographic/observational approaches as well as interviews, community mapping, informal discussions, and participation in the ecotourism projects themselves, sometimes as advisors and sometimes as actual participants. Because our methods were different for each case study, we describe in more detail our specific approaches as we move through those cases. To discuss the relationship between leisure and labor in ecotourism projects, we first turn to literature on de/coloniality that informs how we might understand and frame the "Great" Outdoors within and through the colonial/racial gaze. Much of the decoloniality literature is theoretically focused and/or on settler colonialism and/or Central/South America; we hope with our case studies to bring specificity to what decolonizing practice and thinking might look like. Ultimately, we argue that while we believe ecotourism involves racialized/nationalized/classed seeings and experiences, local communities perceive ecotourism as a possible revenue and cultural engagement enterprise. We suggest, in the end, that local community projects, like the cases we discuss here, have the best opportunity for providing meaningful revenue and actual interactions, even as we recognize these suggestions are fraught and reside within the neoliberal, globalized economic structures of capitalism. However, there is a great need for developed ecotourism policy, greater industry connections, improvement of services (ranging from homestays to transportation), reduction of imported goods/foods and waste, and consideration of gendered labor. Ultimately, we contend that ecotourism, while highly desired by communities and ecotourists alike, remains situated in the colonial, racialized gaze and experience, in which the Westerner/Global Northerner/ privileged tourist is able to demand attention and hospitality in ways that perpetually subjugate Indigenous and other local communities. And yet, our critique is not likely to end such programs; we ask that academics, tourists, and communities alike consider the implications of such endeavors.

\section{Ecotourism as Leisure/Labor and Colonial/ Racial Gaze}

Ecotourism destinations are marketed in specific ways that construct important meaning and experience for both tourists and industry workers. For tourists, expectations are formed through rhetorically constructed messages such as exotic adventure. Such expectations then shape how tourists experience and remember their ecotourism activities, with varying degrees of self-awareness and critical consciousness (Sowards, 2012). That is, such experiences can shape the environmental identity of the tourist supposing a critical orientation and cosmopolitan understanding of the world. However, foreign tourists are also people of their own ontologies and cannot help but understand the world through their own privileged, often racialized, nationalized, and classed gaze. The tourist then, engages in a form of colonial/racial gaze when traveling abroad, particularly from the Global North/West (see Crawshaw and Urry, 1997). For ecotourism laborers, such as tour guides, homestay workers, meal preparers, and transportation providers, their experiences are oriented towards the tourist's pleasure and enjoyment; in our case studies, these are often foreigners and out-of-state domestic tourists. That orientation profoundly alters environmental identities in how such workers experience the "Great" Outdoors and natural ecosystems. For workers who may have 
always lived in such environments, to see these worlds through the eyes of outsiders is necessary to provide the ecotourist customer the desired experience. Therein lies the challenge: to see their own worlds from an outsider's perspective, one of leisure, privilege, higher class standing, economic status, colonial language power, and so forth. As Leilani Nishime and Kim D. Hester Williams contend in the introduction of their edited collection, Racial Ecologies, "race is inextricable from our understandings of ecology, and vice versa. In fact, ideologies that define terms such as nature and landscape also subtend categories such as self/other, Asian, and white" (Nishime and Hester Williams, 2018, pp. 3-4, italics in original).

Ideally, travel and tourist experiences enable a different kind of seeing, one that transforms. As Trinh Minh-ha notes,

Every voyage can be said to involve a re-siting of boundaries. The traveling self is here both the self that moves physically from one place to another, following 'public routes and beaten tracks' within a mapped movement, and the self that embarks on an undetermined journeying practice, having constantly to negotiate between home and abroad, native culture and adopted culture, or more creatively speaking, between a here, a there, and an elsewhere (Minh-ha, 1994, p. 9, italics in original).

States of exile, refugeeism, voluntary migration, and national origin/class status deeply inform the traveling self, in ways that a privileged tourist experience of leisure does not. "Colonized and marginalized people are socialized to always see more than their own points of view" (1994, p. 16), while the tourist is often one who explores cultures and natures through myopic consumption and exoticization.

One is aware of differential status when travel is not for leisure, but privilege has the effect of seeing difference through a lens of privileged class and caste status, with less awareness of privileged gaze in juxtaposition to say, refugee or exiles, who are constantly aware of their status, in often racialized ways. Catherine Ramírez (2020) argues that the tourist, in contrast to the refugee, enjoys "the power, privilege, and prestige of elected movement, especially when they bear the right passport, currency, and mode of transportation, be it a reliable car or a private jet" (pp. 113-4). As such, categories of mobile people ranging from tourists and diplomats to immigrants and refugees are hierarchical and racialized in how they arrive and are received, as Ramírez contends. These different types of travel (forced vs. pleasure/leisure) definitively shape how one becomes and evolves from such experiences.

This kind of status and mobility of the Western or Global North tourist, or even the domestic tourist who has the financial resources to travel reflects a privileged way of seeing and not-seeing that local people cannot come to understand, often because of their lack of or limited mobility. Rob Nixon (2011) describes the long-term effects of colonization on how people experience leisure tourism, such as the game lodge in Africa. Discussing Njabulo Ndebele's writings, Nixon describes the game lodge as "free-floating Edenic enclaves of natural time, unmoored from historical memory, clock-time, and the time of labor" (p. 181). As leisure, such lodges as a tourist destination in
African countries shape a form of spectacle and an ecology of looking. Nixon explains that: "In the touristic present, the fraught issue of labor resurfaces through the prism of class, which complicates whatever racial identification the vacationing writer may feel with those who tiptoe around him or her in roles of unobtrusive service" (p. 184). Ndebele, as Nixon explains, questions how he will be seen as an insider/outsider within this white tourist/ non-white laborer community. Similarly, Jamaica Kincaid explores such questions: "How, she exclaims, can the emancipated descendants of slaves celebrate the Hotel Training School 'which teaches Antiguans how to be good servants?"' (p. 185). Nixon further argues that nature tourism in colonized regions and nations reflects politics of looking and enables a white tourist experience without anguished conflict, whereas for the Black tourist, there is a feeling of spectacle and sense that the non-white folks are on display as much as the non-human animals and environments are.

Not only are the actual interactions and experiences concocted to benefit white gaze and privilege, but the way in which such tourists write about their travels re-entrenches racialized narratives. Writing about the histories and origins of Western/ European travelers to the Global South as well as Indians traveling to Europe, Inderpal Grewal illustrates how travel narratives construct identities related to gender, nation, class, and race, as well as labor. Grewal further contends that:

this mode of travel became and is hegemonic to this day [through ...] the deployment of the term travel as a universal form of mobility. Such a use erases or conflates those mobilities that are not part of this Eurocentric, imperialist formation, while including some, like the trope of exile, that reinscribe European hegemonic aesthetic forms. For instance, migration, immigration, deportation, indenture, and slavery are often erased by the universalizing of European travel" (Grewal, 1996, p. 2).

She continues by noting that travel becomes metaphorical in how one comes to understand relational selves in difference across nationalities and class standings as well as the "knowledge" of the Other that one gains from such travel.

While the travelers themselves form some kind of understanding through their gaze of racialized/nationalized/ classed difference, the laborers and other folks in communities who might encounter such tourists struggle with the question of hospitality, that is, how to provide services to the tourist, while existing within this state of the differential. Jacques Derrida, in conversation with Anne Dufourmantelle, theorizes this traveling/ migration question surrounding the meaning of hospitality and foreigner, although their discussion resides within the relationship to father and parricide. The connection Derrida makes is among foreign, hospitality, and identity or being: "the place where the question of the foreigner as a question of hospitality is articulated with the question of being" (Dufourmantelle and Derrida, 2000, p. 9), which can also become a sense of blindness and madness. Derrida also links the notions of home and hospitality, similar in some ways to Grewal's connection between home and harem. Although Derrida invokes technology as a violation of home, we 
can also think through the power structures of tourism, in "homestays" for example, as both the violation of home and hospitality as well as the invited guest as parasite. While Derrida dichotomizes guest and parasite, in the field of tourism, such meaning is collapsed, as the guest becomes a parasitic form of monetary capital in the context of the "homestay" and laboring and hosting bodies. While guests may be invited, the power imbalances related to race, nationality, caste/class standing, and gender suggest a form of hegemonic hospitality.

So far, we have been discussing the ways in which tourist gaze is racialized/classed (or casted), but gender, in the intersectional margins of race/class/caste, also plays a significant role in the parasitic nature of traveling and touring in the form of leisure. Cynthia Enloe, in her still very relevant book, Bananas, Beaches, and Bases, argues that tourism and travel invoke powerful hierarchies of social and political understanding, particularly within gender dynamics:

Power infuses all international relationship. We would like to imagine that going on holiday to Bermuda rather than Grenada is merely a social, even aesthetic matter, not a question of politics ... Power, not simply taste, is at work here. Ignoring women on the landscape of international politics perpetuates the notion that certain power relations are merely a matter of taste and culture. Paying serious attention to women can expose how much power it takes to maintain the international political system in its present form (Enloe, 1989, pp. $2-3$, italics in original).

Enloe goes on to argue that women become the service workers of the tourism industry, as evidenced in professions such as flight attendants, cleaning personnel, servers, and cooks. Tourists in these senses create intimacy through power relationships, in which expectations for cultural accommodation or adventure are very low, while at the same time invading the spaces/places/senses of people who engage in the labor to ensure that tourists enjoy themselves and acquire the desired engagement: "Often women have been set up as the quintessence of the exotic. To many men, women are something to be experienced" (Enloe, 1989, p. 28). Ecotourism, while presumably more socially, culturally, economically, and politically attuned, cannot avoid these problems, as we examine further in this article, and as have been explored elsewhere both in terms of the gendered nature of forestry and conservation as well as ecotourism more specifically (Husien, 2002; Atje and Roesad, 2004; Arnscheidt, 2009; Liswanti et al., 2011; Mai et al., 2011; Mwangi and Mai, 2011). Various forms of tourism, ranging from hedonistic and deeply problematic forms to the more socially aware forms (such as ecotourism) are all informed by the colonial/racialized gaze in different ways and levels.

\section{Neoliberalisation, Territorialization, and Ecotourism}

The ways in which tourism in general reflects the same hegemonic forms of ideologies related to race, class, caste, and gender, for instance, is further complicated and compounded in globalization and neoliberal politics. That is, we can never escape the paradoxical expectations of critiquing/promoting ecotourism because it is both a capitalistic endeavor that may be a boon for local communities, even while rooted in problematic assumptions. Ecotourism, while touted by the United Nations as a means to generate "economic benefits for host communities, organizations and authorities managing natural areas with conservation purposes" and providing alternative employment and income generation for local and Indigenous communities (UNWTO: World Trade Organization, 2002; Stronza, 2007), has been "far more problematic than UN rhetoric" (Dalgish, 2018). As Dalgish notes, the "pressure to engage in ecotourism is effectively a pressure to subordinate concern for environmental conservation and respect for local communities (which ecotourism ostensibly supports) to 'concern for attracting ecotourists and their money"' (West and Carrier, 2004, p. 491 in Dalgish, 2018).

This "postneoliberal environmental-economic paradigm" as posited by McAfee (1999), often reinforces exploitative capitalist relations by pushing developing nations to "sell nature to save it" (McAfee, 1999, p. 133 cited in Dalgish, 2018). According to Igoe and Brockington (2007), neoliberalisation is part of a global process that "involves the re-regulation of nature through forms of commodification" leading to new types of "territorialization-the partitioning of resources and landscapes in ways that control, and often exclude local people" (p. 432, 436). This territorialization is a form of reregulation that often creates "new types of values and make those values available to national and transnational elites" (p. 432). According to Ferguson (2006), protected areas in developing countries are primary examples of such "territorialized spaces of high biodiversity value" that have been "reregulated to give them new types of economic value and to make that value available to transnational interests and national elites, often at the expense of local rural communities" (Ferguson, 2006 cited in Igoe and Brockington, 2007, p. 441). Carrier and Macleod (2005) extend Marx's (1867) notion of "fetishization of commodities"-or the "tendency to present the commodity for sale in a way that obscures the social relations and situations that bring it into existence and to the attention of the potential buyer" (p. 329) to ecotourism, which "seeks to manage and insulate ecotourists from the realities and contexts of their destinations" (Dalgish, 2018).

These forms of touristic travel to experience nature and culture in leisure form then, are racialized, colonized, gendered, and classed/casted practices as part of the neoliberal globalization. Whether tourists travel to places like India and Indonesia from the West as white or non-white, the Western/Global North lens still reflects a colonizing and racialized gaze. And domestic tourists, such as those traveling within Indonesia and India, embody a class/caste status marked by difference in language, food, culture, caste/class, and religion that frames tourists' experiences in relation to those who work within the tourism industry. In what follows, we expand on this argument in our case studies to explore how differences in leisure and labor complicate goals of ecotourism as experiences in the "Great" Outdoors to empower local communities through income streams and work. 
In order to understand how leisure and labor function in small ecotourism projects in rural communities, we each worked within such communities in fieldwork for larger projects. Paulami has worked with local and Indigenous communities in East Sikkim for the past 12 years, initially as part of her MS research curriculum, and later as part of her doctoral and postdoctoral research work. Her work with rural forest dependent communities in East Sikkim focuses on community based natural resource management, biodiversity conservation, ecotourism practices, and community capacity building. Stacey has worked intermittently in Indonesia for the past 25 years, focused on environmental issues related to conservation, tourism promotion, agroforestry, and environmental campaigns in Aceh, North Sumatra, West Java, West Bali, West and East Kalimantan, what is now North Kalimantan, and South and North Sulawesi. Her work has been part of partnerships and collaborations with local organizations and the global environmental organization Rare, as well as university partnerships, including the Universitas Mulawarman (in East Kalimantan, Indonesia). We now turn to our specific case studies to explain and outline a few of the emerging issues related to experiences of labor/leisure in the "Great" Outdoors conceptualized through ecotourism experiences.

\section{Case Study: Sikkim, India: Neoliberal Failings}

In the following sections, Paulami shares stories from the field-her own experiences and voices of local host communities engaged in ecotourism promotion and development in the Rongli and Phadamchen Territorial Forest Ranges, East Sikkim, India. The experiences shared here are a part of Paulami's doctoral dissertation research conducted in East Sikkim between 2012-2016. She adopted a qualitative, naturalistic inquiry based on multi-sited ethnographic research. Prior to her doctoral dissertation fieldwork, Paulami spent a couple of years with local community members in this region, learning their language, cultural norms, traditions, and ways of life (Banerjee, 2016). Her research team recruited participants by word of mouth, face to face interactions, emails, and phone calls (where possible). The team interviewed over 300 local residents from a wide variety of sociodemographic groups between 2012-2016 (Banerjee et al., 2019). Interview data was supplemented by detailed observational fieldnotes (Allen, 2017). To ensure data comparability and consistency, two interviewers were trained with a strict interview protocol (Lincoln and Guba, 1985). Interviews were conducted in Nepali, Hindi, Bengali, or English depending on the participant's preference. Interviews lasted 20-30 min and were audiotaped with the consent of participants. All interviews were transcribed verbatim and translated into English where applicable. All non-English interviews were back translated to ensure accuracy (Brislin and Freimanis, 2001). As a form of member check, we sent a set of transcribed interviews to study participants for clarifications, feedback, and validation (Birt et al., 2016; Doyle, 2007).
Sikkim, a landlocked northern state of India, is in the foothills of the Eastern Himalayas and part of the IndoBurma global biodiversity hotspot (Myers et al., 2000). Home to the Khangchendzonga National Park, a UNESCO world heritage site with deep natural and cultural significance, Sikkim includes one of India's largest forested areas, with $47.1 \%\left(3,344 \mathrm{~km}^{2}\right)$ of its area under forest cover (Government of Sikkim, 2015). More than 95\% of Sikkim's forested area is designated as statutory forest, meaning it is reserved or protected, usually for conservation purposes (Banerjee et al., 2020). With its varied natural beauty and rich cultural heritage, Sikkim has seen an exponential growth in the tourism sector over the last decade making it one of the most important drivers of the state economy (Government of Sikkim, 2016). With an $84 \%$ year-over-year (YOY) growth in the number of tourists visiting the state in 2017, Sikkim has emerged as one of the most popular tourism destinations in Northeast India (Statista Research Department, 2021). The neighboring state of West Bengal, India, is the main domestic market for Sikkim, currently accounting for $60 \%$ of all domestic visitors. International arrivals in Sikkim have increased steadily over the last few years with Nepal, United States, Germany, United Kingdom, and France as the largest international tourist markets (Government of Sikkim, 2016).

The concept of ecotourism in Sikkim was introduced in 2002 with the commencement of the South Asian Regional Conference on Ecotourism organized by the International Ecotourism Society and Ecotourism and Conservation Society of Sikkim with support from United Nations Development Program and the Ministry of Tourism (Bhutia, 2021). Newly established village homestays across the state became the "new tourism products" that would ensure economic benefits to local and Indigenous communities. With the adoption of the Sikkim Ecotourism Policy, 2012 (subsequently State Tourism Policy, 2015, 2016 and 2018), and Sikkim Registration of Homestay Establishment Rules, 2013, ecotourism or Community-Based Ecotourism (CBET) established itself as an important revenue generator for the state of Sikkim (Government of India, 2013). According to the State Tourism Policy 2016:

Sikkim with its plethora of ethnic communities has tremendous potential for offering tourists a multidimensional cultural experience. At the heart of the rural experience are the homestays spread across the state which provide a glimpse into the village lifestyle and culture. Ethnic cuisine and food products, organic produce, ethnic songs and dances, traditional dresses, handicrafts, vernacular architecture, festivals, traditional medicines, folktales, are some of the items on offer in the cultural basket (Government of Sikkim, 2016, p. 27).

As per the directives of the Sikkim Ecotourism Council, an autonomous council with a village-level operational system, the Ecotourism Directorate (ED) of the Forest, Environment and Wildlife Management Division (FEWMD) is responsible for the 
execution of ecotourism programs in the state, including monitoring, evaluation, research, and development.

Paulami: Over the course of several years that I spent in the Rongli and Phadamachen Territorial Forest Ranges, I stayed with three separate host families that were willing to share their family living arrangements with me with open arms. The living arrangements were quite basic-I would get my own bed in a shared room (sometimes a separate room, if available) and would share meals with the host family for an agreed upon monthly rent that ranged between USD 100-180. Over the course of the 6 years spent with the host families, two families converted their homes into village homestays to cater to the growing influx of ecotourists in the region.

I personally stayed with various families as part of their homestay business. One of families I stayed with illustrates the way in which homestays are developed to cater and provide hospitality to domestic and foreign tourists alike. This family of four lived in their single storied, two bedroom home constructed on ancestral land in the 1970s. With a modest monthly income and two young children to support, the family decided to convert their home into a village homestay in 2013. With the head of the family (in this case the father) working away from home on a contractual job for the better of the year, it was the mother's (age: 39 years, farmer) responsibility to apply for loans and required permits, hire contractors to remodel the house as per state regulations, reach out to travel agents to enlist their homestay, and to personally look after the day-to-day management of the homestay during tourist seasons. What started out as a means to supplement their household income ended up as a failed endeavor within a short span of 3 years. The semi-finished rooms in the family home are a quiet reminder of what could have been for the family. Back in 2017, the family was struggling to repay large loan amounts, an impending repossession of a leased tourist vehicle, and the possibility of being displaced from their ancestral land. As the woman/mother in this family explained in her own words:

I did not know what I was signing up for. It seemed like a great idea at that time, and my husband and I jumped at the opportunity. I had no training or previous experience. I am a farmer; my father was a farmer. No one helped me, I just followed others and did what was told by the [tourist] agents from Siliguri [non-local agents] (Respondent 072, farmer).

While the concept of ecotourism has become widely popular in the state due to its largely positive portrayal (Development Alternatives, 2018), tourism capacity building certainly leaves a lot to be desired in the region. Inadequate planning, lack of community training and awareness programs often leave local host communities ill-prepared to own and run their homestays. The dependency on non-local tourist agencies (often established and run by rich businessmen from neighboring states) to promote ecotourism packages lead to revenue leakage. Local host communities, while remaining financially responsible for running the business, often struggle to benefit from the economic opportunities created by their own resources
(Development Alternatives, 2018). According to recent estimates, approximately $61 \%$ of the tourism industry workforce in Sikkim is from outside the state (Development Alternatives, 2018).

A product of neoliberal conservation (Igoe and Brockington, 2007; Kline and Slocum, 2015), ecotourism, thus, often ends up as a practice where "nature and poor communities can be represented the way they 'ought to be' in order to convince investors, tourists and policy makers of their value" (Büscher, 2010, p. 261). Further, this "intrusion of guests," as explained by King and Stewart (1996) not only commodifies the local environment and culture, but also their labor. According to the authors:

the commodification of nature implies a change in the meaning of their environment from a source of direct sustenance with a use value to a commodity with an exchange value. This change expresses a shift in the relationship between the indigenous people and their environment, from one of working with the land to one of working for tourists (who observe the land)...hence, the commodification of nature not only changes an indigenous people's view of their places, but also their view of themselves (p. 296).

The way in which local communities experience the promise of ecotourism, is shaped by what they perceive they need to do to meet the tourist demand that manifests through the traveler's gaze, demand for hospitality, and the all-encompassing servicing of tourist privilege. Instead of focusing on the land or conservation matters, ecotourism requires local people to shift their thinking to understanding dominant structures related to the commodification of nature and the power imbalances related to race, nationality, class, and caste.

In the case of Sikkim, instances of such commodification of labor and nature in racialized form were commonly reflected in respondents' stories. As one community member explained:

\section{Language barriers often led to miscommunications and the guests became upset. We ended up paying an agent from [West] Bengal to show the tourists around. My family was mainly involved with preparing meals, serving, and cleaning. It was not what we had expected. We wanted to show the guests around, involve them in our cultural traditions, but we could not as we often struggled to communicate clearly (Respondent 073, student/farmer).}

As this story illustrates, language is identified as the barrier, but the underlying power differentials of race/ethnicity and caste emerge as important factors, in which this family is relegated to the "dirty work" of cleaning and serving rather than the relatively more equalizing role of "teacher" or conveyor of cultural knowledge. The "guests" failed to learn from their hosts and hospitality is reduced to service.

Further, in many instances, the day-to-day management of homestays were left to the women in the households while the 
male members commonly worked away from home. Payments and other financial matters, however, were mostly handled by the male members. In households where the husband (head of the family) was absent, the father-in-law or other senior male members would take on the financial management of the business. Tourism activities, thus, as explained by FigueroaDomecq and Segovia-Perez (2020), are often built on "gendered, complex and varied social realities and relationships that are usually hierarchical and unequal" (p. 255). Kinnaird and Hall (1996) use the lens of the gendered host to understand who "carries out carrying out the work, how this distribution of work is constructed and how the patriarchal power structures are articulated" [Kinnaird and Hall, 1996 cited in; Figueroa-Domecq and Segovia-Perez, 2020, p. 255). Examples of gendered marketing (Kinnaird and Hall, 1996)] whereby sexuality and gender relations define and shape how tourism is developed, exoticized, and promoted abound in East Sikkim. Photographs of women in their traditional ethnic outfits participating in local rituals, folk dances, worshipping ancestral gods and local deities are commonly used in tourism brochures and guest handbooks to promote the "authentic experiences" for the travelers. This exoticization of a place and its people, as pointed out by MacCannell (1984), represent a "staged authenticity" and is merely a social construct. As King and Stewart (1996) explain:

The ecotourist arrives with a reality created from a culturally derived set of images of the host natural environment and culture. Hosts work to maintain the ecotourist's reality by accommodating the images he or she brings. The hosts stage the precise aspects of experience that ecotourists view as marks of authenticity (p. 297; see also Cohen, 1988).

The ecotourism industry, the writers continue, "by its efforts to maintain the reality of ecotourists, can produce contrasts in value and behavior that overwhelm the local culture" (p. 297).

Efforts to align local community development and conservation through ecotourism in Sikkim has, in many cases, not only perpetuated the "historical patterns of inequality, social exclusion, and environmental degradation" (Horton, 2009), but has also reshaped the class, caste, gender, socio-economic, and environmental norms and interrelationships within the unique cultural tapestry of rural Sikkim, interwoven with "legends, myths, rituals, and festivals" (FEWMD, 2011; 2015).

\section{Case Study: West Bali National Park, Indonesia: Gendered/Classed Economies}

In this case study and the case studies of the national parks in the following section, Stacey shares her experiences of working in Indonesia. Methodologically, as Stacey shares in the first person, the work in Indonesia has changed over many years. Her work has been informed by qualitative methods in ethnography, interviewing, observation, and lived experiences (Lindlof and Taylor, 2011; Tracy, 2013).
Stacey: I first began working in Indonesia in 1997 or so, although I had traveled to Indonesia six or more times prior to that. These trips were more preliminary, tourist experiences. As I gained more knowledge and research experience, I began to develop research agendas, beginning with my dissertation work and Fulbright year in Indonesia (2000-2001), in which I engaged in ethnographic, observational research and conducted interviews with people in Kalimantan about how ecotourism to national parks worked, while acting as an ecotourist myself. That work resulted in my dissertation about orangutans and orangutan tourism. Various projects have emerged since then, using the same kind of methodological approach, ethnography, ecotourist participation, and interviews. The following case studies in Indonesia rely on that data collection, across a number of studies with different IRB approved protocols. As we describe elsewhere, various issues emerge from this kind of work (Banerjee and Sowards, 2020). What we describe below is based on the amalgamation of that data collection, in which dozens of interviews were conducted and ethnographic experiences were collected over many years, formally beginning in 2000 .

Located on the northwestern side of Bali, Indonesia lies the West Bali National Park. The park covers around 190 square kilometers (73 square miles), of which are 158 square kilometers (61 square miles) land, and the remainder is sea. This is approximately $5 \%$ of Bali's total land area. To the north, it includes a $1,000 \mathrm{~m}$ (3,300 feet) long beach, reef, and islets (Sowards and Varela, 2013). A seaport at Gilimanuk is west of the park, and the village of Goris is to the east. This national park features forest and ocean habitats, with the Balinese starling (jalak putih or Bali curik, a practically extinct bird) as a key attraction to the park. The park, run by the national park system under the Indonesian federal government's Ministry of Environment and Forestry, features a Balinese starling captive breeding program, as well as forest treks, local homestays, scuba diving, snorkeling, and cultural and religious activities. The area is approximately $50 \%$ Muslim and 50\% Hindu, with a cultural mix of Balinese and Javanese traditions. The nearby village of Sumberklampok and Menjangan Island is where our research team participated in workshops, stayed with families, visited the Balinese starling breeder program, and explored the nearby coral reefs. The purpose of the visit was in part to participate, evaluate and report on the efforts made in ecotourism in the area and to make recommendations to further conservation campaigns. From 2008 to 2015, a university partnership between The University of Texas at El Paso, an international nongovernmental organization, Rare, and the Universitas Mulawarman focused on ecotourism evaluation of homestays and ecotourism experiences in West Bali National Park, along with the small non-governmental organization, Seka, with Stacey (the first author of this essay serving as the Project Director). Through this evaluation, a group of UTEP students and faculty members interviewed local people who wanted to develop ecotourism more fully. In undertaking this evaluation, we focused primarily on what local people could do to improve their ecotourism offerings. While such an approach is practical, it also demonstrates the key argument in this paper, that is, the labor of local people in serving mostly foreign tourists who are on 
holiday and in pursuit of leisure and adventure. What we found is that a great deal of thought and planning goes into the development of homestays, cultural activities, environmental education, and communicating with tourists, while very little thought or preparation is part of the ecotourist mindset.

In learning about ecotourism in this national park, we found that local people in the town of Sumberklampok in West Bali and near the port/docks that lead ships to Java, sought to provide services to those with higher income levels, particularly foreign tourists, such as Australians, New Zealanders, Europeans, North Americans, and Northeast Asians even though Indonesians from other provinces were also frequent tourists to the area. To that end, our main recommendations were: developing English and Japanese language skills (as many foreign tourists speak some level of English), improving services related to accommodation, training local families to understand tourist expectations, training guides on basic ecology and park information, developing environmental policies, arranging for package transportation, and developing cultural activities within the town of Sumberklampok. In addition, the national park is threatened with logging activities; as such Seka, the local non-governmental organization worked to establish an "energy garden," in which fast growing trees were planted and could later be harvested as firewood or for wood carvings (as part of the souvenir market throughout Bali; interview with Istiyarto Ismu, Seka and Rare). Within the energy garden, local farmers could also plant various crops, using an agroforestry diversity approach.

While the local NGO, Seka, was keenly interested in developing a viable ecotourism program, the labor invested into such strategy falls almost entirely upon local people to know, understand, and provide for Western or global North tourists. While the UTEP team worked with Seka on this project, the discussions were mostly about how to make such tourists feel comfortable, adventurous, and environmentally conscious about West Bali National Park and the Balinese Starling so that their experiences of the "Great" Outdoors is one of leisure, relaxation, and maybe a little bit of learning. The burden of cultural knowing, however, falls almost entirely upon local people, such as those who work for Seka. They must adapt their language practices (e.g., by learning English), their homes (e.g., as homestays), their jobs (e.g., as guides when tourists show up), and even their village's cultural activities (e.g., as performances for the tourists).

To take a closer look at the homestay in Sumberklampok, we found that local people opened their relatively small homes (approximately 500-1,000 square feet in most cases) to house tourists. What this means in practice is that the family (ranging from two or more people) moved themselves out of the one or two bedrooms in the home to sleep on mattresses in the kitchen or living room or stayed with other family members in another house. To get a tourist project off the ground literally requires the dislocation or displacement of people from their own homes for the sake of the tourists' benefit and enjoyment. While local people were financially compensated for their homestays, another issue that emerged is profit sharing among local people. That is, we discussed at length with Seka's community leaders about the great need to spread tourists throughout people's homes so that everyone would have a chance to earn some money from the ecotourism project. This example illustrates the very complicated nature of global North/global South power imbalances and relationships among those who want to experience ecotourism as part of their vacation or holiday and those who are laboring to provide such leisure.

In considering how gender, cultural, and religious dynamics factor into such power relationships between tourists and tourism providers, we found that the homestay example further illuminates. For example, the women in each household became responsible for meal provisions, including breakfast, lunch, and dinner as well as snacks and household cleaning. Again, tourists provide money for such services, but the labor adds significant burden to women's work in the home. Cultural and religious differences also play out in small and large ways, ranging from how one cleans oneself after using the bathroom to which hand one uses to eat with, what kind of food is preferred (e.g., bread versus rice), and so forth. The community members, we found, were constantly thinking about how to accommodate ecotourists, while the ecotourists themselves were not. For example, students who participated in this research project and were also ecotourists, complained about the toilets, the food, the sleeping accommodations, and so forth because they had the foreigner tourist privilege to do so. Even though many of these students were Mexican Americans from El Paso, Texas, or Mexicans from the bordering state of Chihuahua, their traveling privilege and sense of "foreignness" was quite striking in how they related to the power differentials of ecotourist status in comparison to local host status. In fact, the racial/ethnic/ linguistic/nationality privileges and lack thereof, are further complicated by the UTEP's team non-whiteness, yet still privileged status. Of course, much more needs to be said about this matter, but in the consideration of space and our focus here, we remind the reader again of the ecotourist's privileged gaze and expectation in the ability/mobility of travel.

Cultural events and performances also took on racialized and gendered roles through the exclusion of women, as we observed in two separate cultural events (Sowards and Varela, 2013). The first was to watch and participate in a traditional Balinese all-girls dance class and performance. The instructors and students were all female and the only males present were one UTEP faculty member, two UTEP affiliated students, and one or two local audience members. The second event was an all-male band at the village center that sang and played instruments to welcome us. Here the only men present were the performers and our group's audience members. No females from the village were present as participants or guests. Both women and men performed in traditional ways in which girls [women] were silent even though visible, while the men were vocal and talkative before and after their performance. After the music performance, we were served dinner, which some of the women had prepared. Then, the male head of household escorted members of our group to their homestays.

The cultural events serve as a racialized, religious, and exoticized Balinese experience. Going back to the work of Clifford Geertz (Geertz, 1973) and his work in Bali, such cultural performances become gazed upon by the foreigner. They literally embody the hospitality mentality and catering to 
the tourist/ecotourist as the sole reason for the performance for the tourist. Ecotourists (or even regular tourists) feel as though they have had a cultural experience. As our team's work expanded, we came to have similar "environmental" experiences. Our viewing/seeing/gaze of the Balinese starling is an excellent example. As the West Bali National Park has been developing a captive breeding program of the basically extinct (in the wild) Balinese starling, we witnessed how community members in collaboration with the national park office were working together to expand the population of the Balinese starling. In some of our homestays and at the national park office, the Balinese starling has been bred to release back into the forests of the national park, thereby removing its essentially extinct status. But again, these experiences are constructed for the foreign tourist, emphasizing their values of cultural and environmental production of the extinct and preservation of cultural tradition. Such activities are almost certainly for the tourist, rather than the communities themselves, thereby emphasizing the racialized/nationalized differences and privileges of these communities of local people and tourists.

\section{Case Study: National Parks in Kalimantan: Exoticization of Cultures/Forests}

There are a number of national parks in the Indonesian side of the island of Borneo; the most prominent and well-known feature orangutan tourism: Gunung Palung National Park (West Kalimantan), Tanjung Puting National Park (Central Kalimantan), and Kutai National Park (East Kalimantan). As stated previously, going back to Stacey's dissertation research (2000-2001) through the university partnership with the Universitas Mulawarman (2012-2015), and a partnership with the non-governmental organization Rare (2008-2020), many aspects of ecotourism in Kalimantan have been addressed in our research (Sowards, 2010; Sowards, 2012; Sowards and Varela, 2013). Rare, and its partnership with UTEP, focused on conservation campaigns in Gunung Palung National Park and Tanjung Puting National Park/Lamandau River Wildlife Reserve, while the Universitas Mulawarman partnership focused on ecological conservation in Kutai National Park. While many local folks are interested in developing ecotourism activities, the conservation campaign development program determined that ecotourism is often not a viable alternative to other, more effective conservation efforts (such as the energy garden in West Bali mentioned above). In Tanjung Puting National Park area, it was determined that a more effective approach to conservation would be to focus on reducing forest fires, while in Gunung Palung, the conservation campaign focused on microlending to reduce illegal logging (interviews with Eddy Santoso, Pak Rituan, Sally Tirtadihardja, Ade Yuliani).

Even as we determined that ecotourism was not really a viable conservation strategy in these locations over a many year period and in consultation with local leaders, that has not stopped the interest from foreign tourists in visiting orangutans and their rainforest habitat. As such, ecotourism might be considered a cosmetic conservation approach, through the process of virtue signaling. That is, tourists want to seem committed to environmental and conservation efforts in appearance or cosmetics, but ecotourism is not really a solution in these areas for a number of reasons. Participation in such ecotourism ventures then, can have the effect of signaling a type of virtuousness, but in practice has little conservation effect. Local people see ecotourism as a neoliberal economic opportunity, that often fails as noted in the East Sikkim case study. Many of the same recommendations our team developed for West Bali National Park also apply to national parks throughout the five provinces of Kalimantan, with the additional recommendation related to respect for wildlife, particularly orangutans. For example, tourists often want to hold or touch orangutans when they see them, even though such interactions are not good for wild animals. In Tanjung Puting National Park, and other places throughout Kalimantan, many orangutans have been rescued from palm oil plantations, forest fires, local communities, and the illegal pet trade (see Sowards, 2006a; Sowards, 2006b). Rescued orangutans are often relocated to rehabilitation or reintroduction centers; one of the biggest and longest programs is in Tanjung Puting National Park, where foreign and domestic tourists travel to see orangutans. Because these orangutans are more accustomed to humans and are often reliant on human-provided food, tourists have opportunities to see orangutans at feeding stations. The tourist desire for up-close experiences with orangutans can prevail over respected ecological practice on how to see orangutans from a distance. While signs and warnings are posted about interacting with orangutans, inevitably, tourists violate or fail to adhere to such prohibitions.

Another popular tourist activity is tree planting. Tourists can buy a small tree and plant it in the rainforest; from our experience, planting a tree feels like a productive and proactive action for conservation. Foreign tourists seem to especially love the idea of planting a tree in an Indonesian rainforest. Yet in reality, the trees are small and may not survive. If they do survive, the conservation effect is quite minimal. Again, tree planting suggests virtue signaling as a feel-good, do-nothing measure for conservation. While the fee covers both any cost of the tree itself and provides some local income, the infrequent ecotourist visits mean that this activity, as well as trekking/hiking, camping, and other adventures are not viable nor sustainable income sources for local people.

In addition to tourist desire for close-up experiences (as is the case in many national parks around the world), in Kalimantan's national parks, another big issue is pollution management. While tourists may provide income to local conservation NGOs, national park offices, and local people, they also generate water and air pollution through the use of gasoline/diesel fueled boats, plastic trash that is not disposed of properly, and sewage and food waste. For example, while visiting Kutai National Park, we took small canoe-type boats upriver from a small town to an area with camp-like wooden structured buildings within the park boundary. The park guides and local people had said they would provide us with meals, yet they brought no cooking instruments nor food to prepare. Instead, they took the canoes back to the town and purchased boxes of prepared meals and brought them back to the park. Because the 
park facilities were rudimentary, there were no bathrooms nor trash disposal facilities. As such, raw sewage, food waste, plastic bags, food boxes, plastic utensils, soda cans, water bottles, and all other waste was dumped under the wooden camp facilities. The lack of trash disposal systems also meant that even beyond our group, much trash ended up in the river, as evidenced by the large amounts of trash we saw in the rivers. The point here is not to blame Indonesian local people for improper disposal, it is to point out that ecotourism facilities are not well equipped to handle small or large groups of people. Trash disposal and sewage are part of the hidden labor and cost to local communities that tourists often do not consider in their ecological footprint.

Similar to the other cases discussed here, gender roles also delineate who participates in what activities. The national park offices in Kalimantan require that foreign tourists are accompanied by a guide or park ranger, who are always men (at least in the UTEP team experiences). Assistants and other related folks are also men. Women are completely invisible except in the case of cultural performances, such as Kenyah dances or even the tourist attraction of seeing "real" Kenyah peoples (one of the sub-Indigenous groups in Kalimantan). That is, tourists/ ecotourists can visit Kenyah long houses, the traditional architectural style of home building in Kalimantan's provinces. One can see the architectural style and also learn about family structures in these houses, while also seeing Indigenous people who are on "display" with their traditional tattoos, betel nut colored teeth, and stretched earlobes. Tourists (both foreign and domestic) take pictures to remember such "exotic" people, once again marking the distinction of leisure and racialized/colonial gaze as well as the labor of performing the "exotic."

This gaze illustrates the ecological and cultural/racial implications of how ecotourism functions in practice. The exoticization and romanticization of Indigenous people, along with the romanticized experiences of tree planting and orangutan holding, become problematic through the ecotourist's cultural privilege and expectation of having such experiences and is manifested through the neoliberal, ecological paradigm. Furthermore, the demand for such experiences shapes how Indigenous/local communities perceive their worth, and their community's/land's worth. Without the demand for such exotic experiences, they might value their land and community through a very localized lens. However, the foreign gaze and demand for hospitality refigures the contours of land and community, in $\mathrm{racialized} / \mathrm{classed} /$ casted ways.

\section{CONCLUSION}

In each of the case studies here, differences and similarities emerge. Each case study presents a different facet of how race is experienced in the "Great" Outdoors, through neoliberal failings, gendered/classed economies, and exoticization of cultures/forests. While both tourists and local people experience the "Great" Outdoors in ecotourism projects, the relationship that each group has is quite different. Tourists seek pleasure, adventure, relaxation, and maybe a little bit of learning. Ecotourists are somewhat more ecologically and culturally conscious of their experiences, but perhaps only at the surface level. Meanwhile, tourist providers, guides, homestay families, and cultural activity organizers are constantly catering to tourist demands and the accompanying problems they bring. For small ecotourism projects, the labor is all encompassing to ensure enjoyment, safety, and needs are met. In thinking back to the colonial and racialized gaze, the way in which each group "looks" at each other is quite different and is certainly marked by significant power imbalances related to money, culture, race, language, gender, and religion. As such, there are a number of challenges that ecotourism projects face as they build such programs to draw in both foreign and domestic tourists. Some of these challenges are practical, others are more rooted in the broader effects of colonialism and its long-lasting legacies. While we recognize suggestions to improve small-scale ecotourism projects are inherently fraught with the same critiques that we present here, we proceed in offering such suggestions as a way to think about practical matters. That is, even as ecotourism projects require, by their very nature, power imbalances, racialized experiences of the "Great" Outdoors, and gendered divisions of labor, we also know that local community members may still want to proceed in developing such programs. In the end, the value and possibility of revenue in neoliberal, globalized economic structures still prevails.

To begin, the regions we have discussed here have no developed tourism or ecotourism policy. The ecotourism concept has been defined by international organizations and is generally accepted for most of the groups and local people we have discussed here. However, stakeholders use the term 'ecotourism' to fit in with their own specific agendas and may not fully understand the complicated aspects of ecotourism as a business. It is apparent that many stakeholders advocating the development of ecotourism are unclear about the realities of the sector, the requirements of demand for this tourism product, and the importance of developing a strong chain linking supply with demand. Many consider ecotourism to be a social net that will alleviate poverty without understanding that ecotourism is first and foremost a business that follows commercial objectives. NGOs and local people can be naïve about the impact that ecotourism will have on the well-being of local communities. Many NGOs encourage local communities to set up ecotourism businesses or services and build up their expectations in the hope that tourism will bring a steady income. They provide training and mentoring and may also be in a position to access funding to help them develop the products such as setting up homestays and guiding services. They often pick communities in areas with little income generation opportunities but with ecotourism potential thinking that tourists will come if the local community is ready to serve them. Usually these are not established tourism destinations. They need to be developed, adapted to the expectations of the markets that the destination can potentially attract, and then properly marketed. Establishing a tourism destination is a process that takes time and requires investment and strong marketing which neither the NGOs nor the local communities generally have. They focus too much on building up supply but not on developing demand. When demand fails to materialize, the product on which so much 
expectation has been placed deteriorates through lack of use and maintenance. The local communities become disillusioned and abandon their ecotourism aspirations. For example, the Sikkim Tourism Department's current village ecotourism strategy is to increase the number of villages offering ecotourism products. The absence of a viable marketing strategy amidst the increasing number of available homestay facilities, however, creates unhealthy competition amongst villages, lowering profitability of such establishments (Japan International Cooperation Agency, 2009).

Another challenge is that village ecotourism initiatives have very weak linkages with industry partners. Tour operators are often unaware of the opportunities that are available to include village tourism in their product offerings and how they can reserve homestays that are suitable for their business. While local tourism management committees do not have the necessary skills, experience, or resources to promote ecotourism in an already highly competitive marketplace, there are cases where local NGOs have advised communities not to trust tour operators, especially from outside of Sikkim, because they take commission. And yet, due to a dearth of local tourist operators who can provide competitive rates to homestay owners, locals are often forced to rent their homestays through out-of-state tourist agents. This contributes to revenue leakage, as these tourist agents take a cut of the profit that does not end up in the hands of the local people (Japan International Cooperation Agency, 2009).

While tourists may opt to stay in homestays, the quality of the homestays in Sikkim, Bali, and locations in Kalimantan is often not up to tourists' standards (Japan International Cooperation Agency, 2009). These homestays often lack attached bathrooms (often a key demand for domestic tourists), adequate trash disposal facilities, and often, based on elevation and topography without reliable or often without any telecommunication services such as telephone/cellphone coverage and internet. Uninterrupted power supply along with easy access to main roads are also important concerns in many areas of rural Sikkim, Bali, and Kalimantan. For example, ecotourism locations may not be far in terms of miles/ kilometers, but road quality can mean many hours by bus or car to travel to these locations. Similarly, as discussed above, homestays in Bali or camp structures in Kalimantan may not provide bathroom facilities, trash disposal services, or private rooms for guests as may be desired. Tourists may prefer the "camping" effect, but the waste disposal management is a demonstrated problem.

Another issue is that the tourism and ecotourism sectors use too many imported goods and employ too many workers from outside the state, thus reducing the benefits to local economies. For example, if transportation is offered by a tourist operator from outside the local community because local folks do not have busses/ large cars/vans/boats, online travel reservation systems, access to the internet (or even phone services), and/or English language skills, hiring from outside is lost revenue for that community. Communities need capital and skills investment in order to keep higher levels of revenue within their communities.

Furthermore, women are likely to engage in behind-thescenes work, adding to their already double-burdened labor.
As Nani Husien (2002) demonstrates, women in her case study (in East Kalimantan province) have the double burden of working as well as taking care of children, collecting firewood, housekeeping and cleaning, cooking, cleaning, and maintaining water supplies. As we witnessed, women in communities that desire ecotourism development become responsible for the added labor of cooking and cleaning for tourists. They may also take on cultural performance. That is, in West Bali National Park for example, part of the tourist draws is cultural performances of Balinese dance and theater. In Kalimantan, it might be more related to Indigenous cultural performances (such as the Kenyah people's cultural traditions). Because dance is often the domain of women and young girls, we found in these communities some added labor in cultural performance as well as in the set up and entertainment aspects related to such performances, which might involve serving food and drink to go along with the performances. Women can become exoticized through dance performances, Indigenous tattoos and earlobe stretching, and/or betel nut chewing as part of the tourist gaze, not to mention their more silent roles in care taking, food preparation, and household management.

Furthermore, cultural factors also play a role in how we understand gender differences in forestry practices and conservation. In interviews with women and men, there are gendered expectations that women will take care of the family, and there is a heavy emphasis on heteronormativity and traditional family life. Many Indonesians (and to some extent, global Northerners too) resist the idea that women should study forestry or environmental problems because of the field work and travel required to do so. Cultural and religious factors are important to understanding the gendered nature of forestry and conservation in Indonesia, but most importantly, women play important roles in these sectors, given their roles in agricultural production, forest products, and furniture making (see Mwangi and Mai, 2011 for more on these subjects). These are also gendered sectors, and more research is needed on how women participate differently or not at all in such industries or income sources.

Finally, as we have discussed here, ecotourism projects establish a leisure/labor dichotomy illustrated through the power imbalances related to caste, class, race, language, ability, and gender. While our last point here is more critical of broader colonial relationships of power, it is also important to consider how such projects reinforce, maintain, and perpetuate how the people of the world understand social positionings. Some might argue that ecotourism can provide learning experiences and opportunities not just about ecology and cultural practices. However, as Gail Lash notes, even when tourists might learn something, ecotourism can also corrode the flourishing of traditions and cultures: "uncontrolled growth of tourism and the influx of western values can erode local culture" (Lash, 1997, p. 4). Community-based ecotourism projects, like those we have described in India and Indonesia, have the potential to empower local communities, even if power imbalances are almost impossible to erase or diminish. Scheyvens (1999) contends that such programs can provide economic, psychological, social, and political dis/empowerment, depending on demand 
and community collaboration in meeting that demand. In our experience in studying these locations, tourists and ecotourists alike, in their expectation of leisure, enjoyment, and adventure, are at best only minimally conscious of the colonial, racial, and power politics at play. Privilege is disguised as cultural and ecological learning, relieving tourist responsibilities, or absolving guilt in cultural and environmental appropriation. Leisure forms of ecotourism provide a connection to the "Great" Outdoors in significant ways that can be life altering and profound, but that often comes at the expense of local people. While labor forms of ecotourism provide sources of income and cultural interactions that might be valuable to local people, the power imbalances remain, and ecotourism projects remain imperfect approaches to conservation, cultural engagement, and gendered/racialized relations of labor and leisure.

\section{DATA AVAILABILITY STATEMENT}

The original contributions presented in the study are included in the article/Supplementary Material; further inquiries can be directed to the corresponding author.

\section{REFERENCES}

Allen, M. (2017). The SAGE Encyclopedia of Communication Research Methods, 14. Thousand Oaks, CA: SAGE.The SAGE Encyclopedia of Communication Research Methods doi:10.4135/9781483381411

Arnscheidt, J. (2009). 'Debating' Nature Conservation: Policy, Law, and Practice in Indonesia. A Discourse Analysis of History and Present. Leiden, Netherlands: Leiden University Press.

Atje, R., and Roesad, K. (2004). Who Should Own Indonesia's Forests? Exploring the Links between Economic Incentives, Property Rights and Sustainable forest Management. CSIS Economics Working Paper Series. Available: http://www. csis.or.id/papers/wpe076.

Banerjee, P., and Sowards, S. K. (2020). Working across Languages/cultures in International and Environmental Communication Fieldwork. J. Int. Intercultural Commun., 1-21. doi:10.1080/17513057.2020.1850844

Banerjee, P., Wang, H.-H., Peterson, M. J., Grant, W. E., and Peterson, T. R. (2019). Collaborative Modeling and Social Learning in the Context of Joint Forest Management in East Sikkim, India. Front. Environ. Sci. 7 (154), 1-16. doi:10.3389/fenvs.2019.00154

Banerjee, P., Peterson, T. R., Liles, M. J., Banerjee, R., and Peterson, M. J. (2020). How Key Sociodemographic and Spatial Variables Influence Stakeholders' Social Control Frames Regarding Natural Resource Conservation in East Sikkim, India. Biol. Conserv. 245, 108528. doi:10.1016/j.biocon.2020.108528

Banerjee, P. (2016). "Community Conversations on Conservation," in Environmental Communication and Community: Constructive and Destructive Dynamics of Social Transformation. Editors T. R. Peterson, H. L. Bergea, A. M. Feldpausch-Parker, and K. Raitio (New York: Routledge), 99-123. doi:10.4324/9781315691176-6

Bhutia, S. P. (2021). Understanding Tourism and its Scope in Sikkim. Sikkim Chronicle. Available at: https://www.thesikkimchronicle.com/understandingtourism-and-its-scope-in-sikkim.

Birt, L., Scott, S., Cavers, D., Campbell, C., and Walter, F. (2016). Member Checking: A Tool to Enhance Trustworthiness or Merely a Nod to Validation? Qual. Health Res. 26 (13), 1802-1811. doi:10.1177/1049732316654870

Brislin, R. W., and Freimanis, C. (2001). "Back-translation: A Tool for CrossCultural Research," in An Encyclopedia of Translation: Chinese-English, English-Chinese. Editors S.-W. Chan and D. E. Pollard (Hong Kong: The Chinese University Press), 22-40.

\section{ETHICS STATEMENT}

The studies involving human participants were reviewed and approved by UTEP's Office of Research and Sponsored Programs. Written informed consent for participation was not required for this study in accordance with the national legislation and the institutional requirements. Written informed consent was obtained from the individual(s) for the publication of any potentially identifiable images or data included in this article.

\section{AUTHOR CONTRIBUTIONS}

Both authors contributed equally. PB focused on the East Sikkim section; SKS focused on the Bali and Kalimantan sections.

\section{FUNDING}

United States Agency for International Development under award agreement No. AID-497-A-12-00008; travel grants from Texas A\&M University, and the University of Texas at El Paso.

R. Buckley (Editor) (2004). Environmental Impacts of Ecotourism (Cambridge, MA: CABI Publishing).

Büscher, B. (2010). Derivative Nature: Interrogating the Value of Conservation in 'Boundless Southern Africa'. Third World Q. 31 (2), 259-276. doi:10.1080/ 01436591003711983

Carrier, J. G., and Macleod, D. V. L. (2005). Bursting the Bubble: The SocioCultural Context of Ecotourism. J. R. Anthropol. Inst. 11, 315-334. doi:10.1111/ j.1467-9655.2005.00238.x

Crawshaw, C., and Urry, J. (1997). "Tourism and the Photographic Eye," in Touring Cultures: Transformations of Travel and Theory. Editors C. Rojek and J. Urry (New York, NY: Routledge), 176-195.

Dalgish, C. (2018). Is Ecotourism a 'magic Bullet' for Sustainable Development? - an Anthropological Essay. medium.com. Available: https://medium.com/ environmental-intelligence/is-ecotourism-a-magic-bullet-for-sustainabledevelopment-an-anthropological-essay-c60c1062aaff.

Development Alternatives (2018). Sikkim's Eco-Tourism Evolution. Green Economy Coalition. London: International Institute of Environment \& Development. Retrieved from: https://www.greeneconomycoalition.org/ news-and-resources/sikkims-eco-tourism-evolution (Accessed June 18, 2021).

Doyle, S. (2007). Member Checking with Older Women: A Framework for Negotiating Meaning. Health Care Women Int. 28 (10), 888-908. doi:10.1080/07399330701615325

Dufourmantelle, A., and Derrida, J. (2000). Of Hospitality: Anne Dufourmantelle Invites Jacques Derrida to Respond. Stanford, CA: Stanford University Press.

Enloe, C. (1989). Bananas, Beaches, and Bases: Making Feminist Sense of International Politics. Berkeley, CA: University of California Press.

Ferguson, J. (2006). Global Shadows: Africa in the Neoliberal World Order. Durham, USA: Duke University Press.

FEWMD (2011). Sikkim Ecotourism Policy. Retried from http://sikenvis.nic.in/ WriteReadData/UserFiles/file/ET_Policy_book_Pages_20-01-12[1].pdf (Accessed June 10, 2021)

FEWMD (2015). Forestry and Environment Mission Sikkim 2015. Retrieved from: http://www.sikkimforest.gov.in/Reports\%20and\%20Publications/vision2015/ Forestry\%20and\%20Environment\%20Mission\%20Sikkim\%20-\%202015.pdf (accessed June 28, 2019).

Figueroa-Domecq, C., and Segovia-Perez, M. (2020). Application of a Gender Perspective in Tourism Research: a Theoretical and Practical Approach. Jta 27 (2), 251-270. doi:10.1108/JTA-02-2019-0009

Geertz, C. (1973). The Interpretation of Cultures. Basic Books. 
Government of India (2013). Tourism Survey Report for the State of Sikkim (June 2011-May 2012). Ministry of Tourism, Market Research Division, Government of India. New Delhi, India: Datamation Consultants Pvt. Ltd.

Government of Sikkim (2015). Sikkim Human Development Report 2014: Expanding Opportunities, Promoting Sustainability. New Delhi: Routledge.

Government of Sikkim (2016). State Tourism Policy 2016. Gangtok, India: Government of Sikkim. Available: https://investuttarakhand.com/themes/ backend/acts/act_english1575310565.pdf.

Government of Sikkim (2018). State Tourism Policy 2018. Gangtok, India: Government of Sikkim. Available: https://www.newtourismfoundation.com/ wp-content/uploads/2020/03/Sikkim_Tourism_Policy_10.pdf.

Greening Economic Sectors (2018). Sikkim's Eco-Tourism Evolution. Available: https://www.greeneconomycoalition.org/news-analysis/sikkims-eco-tourismevolution\#note-ref- 4 .

Grewal, I. (1996). Home and Harem: Nation, Gender, Empire, and the Cultures of Travel. Durham, NC: Duke University Press.

Honey, M. (1999). Ecotourism and Sustainable Development: Who Owns Paradise? Washington, DC: Island Press.

Horton, L. R. (2009). Buying up Nature: Economic and Social Impacts of Costa Rica's Ecotourism. Latin Am. Perspect. 16636 (3), 93-107. doi:10.1177/ $0094582 \times 09334299$

Husien, N. (2002). Gender Perspective in Forestry. Paper presented for the Center for Social Forestry, Universitas Mulawarman. Samarinda, East Kalimantan, Indonesia.

Igoe, J., and Brockington, D. (2007). Neoliberal Conservation: A Brief Introduction. Conservation Soc. 5 (4), 432-449. Available at: http://www.jstor.org/stable/ 26392898.

Japan International Cooperation Agency (Jica) (2009). Preparatory Study on Integrated Project for Sustainable Development of forest Resources in Sikkim. Gangtok, Sikkim, India: Department of Forest, Environment and Wildlife Management, Government of Sikkim.

King, D. A., and Stewart, W. P. (1996). Ecotourism and Commodification: Protecting People and Places. Biodivers Conserv. 5 (3), 293-305. doi:10.1007/BF00051775

Kinnaird, V., and Hall, D. (1996). Understanding Tourism Processes: A GenderAware Framework. Tourism Manage. 17 (2), 95-102. doi:10.1016/02615177(95)00112-3

Kline, C. S., and Slocum, S. L. (2015). Neoliberalism in Ecotourism? the New Development Paradigm of Multinational Projects in Africa. J. Ecotourism 14 (23), 99-112. doi:10.1080/14724049.2015.1023731

Lash, G. (1997). What Is Community-Based Ecotourism? Vermont: The Ecotourism Society. Available: https://static1.squarespace.com/static/ 5b4ffce65ffd203343139185/t/5b52a2b18a922d868ebac7ee/1532142265311/ Ecotourism.pdf (Accessed June 2021).

Lincoln, Y., and Guba, E. G. (1985). Naturalistic Inquiry. Newbury Park, CA: Sage.

Lindlof, T. R., and Taylor, B. C. (2011). Qualitative Communication Research Methods. 3rd ed. Los Angeles, CA: Sage Publications.

Liswanti, N., Sheil, D., Basuki, I., Padmanaba, M., and Mulcahy, G. (2011). Falling Back on Forests: How Forest-Dwelling People Cope with Catastrophe in a Changing Landscape. Int. For. Rev. 13 (2), 442-455. doi:10.1505/ 146554811798811326

MacCannell, D. (1984). Reconstructed Ethnicity Tourism and Cultural Identity in Third World Communities. Ann. Tourism Res. 11, 375-391. doi:10.1016/01607383(84)90028-8

Mai, Y. H., Mwangi, E., and Wan, M. (2011). Gender Analysis in Forestry Research: Looking Back and Thinking Ahead. Int. Forest. Rev. 13 (2), 245-258. doi:10.1505/146554811797406589

Marx, K. (1867). 'The Fetishism of Commodities and the Secret Thereof in Capital. (New York: International Publishers) Vol. 1.

McAfee, K. (1999). Selling Nature to Save it? Biodiversity and Green Developmentalism. Environ .Plan. D. Soc. Space 17 (2), 133-154.

Minh-ha, T. T. (1994). "Other Than Myself/my Other Self," in Travellers' Tales. Editors G. Robertson, M. Mash, L. Tickner, J. Bird, B. Curtis, and T. Putnam (New York: Routledge), 9-26.

Mwangi, E., and Mai, Y. H. (2011). Introduction to the Special Issue on Forests and Gender. Int. Forest. Rev. 13 (2), 119-122. doi:10.1505/ 146554811797406561
Myers, N., Mittermeier, R. A., Mittermeier, C. G., da Fonseca, G. A. B., and Kent, J. (2000). Biodiversity Hotspots for Conservation Priorities. Nature 403, 853-858. doi:10.1038/35002501

Nishime, L., and Hester Williams, K. D. (2018). "Introduction: Why Racial Ecologies," in Racial Ecologies. Editors L. Nishime and K. D. Hester Williams (Seattle, WA: University of Washington Press), 3-15.

Nixon, R. (2011). Slow Violence and the Environmentalism of the Poor. Cambridge, MA: Harvard University Press.

Ramírez, C. (2020). Assimilation: An Alternative History. Oakland, CA: University of California Press.

Rubita, I. (2012). Sustainability Issue in Tourism: A Case Study of Yuksam Village, Sikkim. Atna 7 (2), 117-129. doi:10.12727/ajts.8.7

Sarkar, D. (2020). Exotic Sikkim Starts Preparing its Tourism Revival Plan. Retrieved from: https://economictimes.indiatimes.com/industry/services/travel/exotic-sikkimstarts-preparing-its-tourism-revival-plan/articleshow/75725686.cms?from $=\mathrm{mdr}$ (Accessed June 20, 2021).

Scheyvens, R. (1999). Ecotourism and the Empowerment of Local Communities. Tourism Manage. 20, 245-249. doi:10.1016/s0261-5177(98)00069-7

Sowards, S. K., and Varela, D. (2013). "Ecotourism, Development Aid, and Project Management: Gendered Frames of Status and Privilege," Paper presented at the National Communication Association Conference. Washington, D.C.

Sowards, S. K. (2006a). Identification through Orangutans: Destabilizing the Nature/ culture Dualism. Ethics Environ. 11 (2), 45-61. doi:10.2979/ete.2006.11.2.45

Sowards, S. K. (2006b). "Chapter Six: Rhetoric of the Perpetual Potential: A Case Study of the Environmentalist Movement to Protect Orangutans," in Environmental Communication Yearbook. Editor S. Depoe (Mahwah, NJ: Lawrence Erlbaum Associates), 3, 115-135. doi:10.1207/s15567362ecy0301_6

Sowards, S. K. (2010). Communicative Activities in Community Ecotourism in Kalimantan, Indonesia. J. Dev. Commun. 21 (1), 5-16.

Sowards, S. K. (2012). Expectations, Experiences, and Memories: Ecotourism and the Possibilities for Transformations. Environ. Commun. 6 (2), 175-192. doi:10.1080/17524032.2012.666986

Statista Research Department (2021). Year-on-year (YoY) Growth in the Number of Tourist Visits in India in 2017, by Leading State. from https:// www.statista.com/statistics/1044620/india-yoy-growth-in-tourist-numberby-state/(Retrieved September 25, 2021).

Stronza, A. (2007). The Economic Promise of Ecotourism for Conservation. J. Ecotourism 6 (3), 210-230. doi:10.2167/joe177.0

Tracy, S. J. (2013). Qualitative Research Methods: Collecting Evidence, Crafting Analysis, Communicating Impact. Hoboken, NJ: Wiley-Blackwell.

UNWTO: World Trade Organization (2002). Ecotourism and Protected Areas. Available: https://www.unwto.org/sustainable-development/ecotourism-andprotected-areas (Accessed June 18, 2021).

Weaver, D. (2001). Ecotourism. Milton, Queensland: John Wiley \& Sons, Australia, Ltd.

West, P., and Carrier, J. G. (2004). Ecotourism and Authenticity. Curr. Anthropol. 45 (4), 483-498. doi:10.1086/422082

Whelan, C. (2013). Spotlight on Sustainability: Preserving Cultures through Ecotourism. Good Nature Travel. WWF. Available: https://www.nathab.com/ blog/spotlight-on-sustainability-preserving-cultures-through-ecotourism/ (Accessed June 21, 2021).

Conflict of Interest: The authors declare that the research was conducted in the absence of any commercial or financial relationships that could be construed as a potential conflict of interest.

Publisher's Note: All claims expressed in this article are solely those of the authors and do not necessarily represent those of their affiliated organizations, or those of the publisher, the editors and the reviewers. Any product that may be evaluated in this article, or claim that may be made by its manufacturer, is not guaranteed or endorsed by the publisher.

Copyright (๑) 2021 Sowards and Banerjee. This is an open-access article distributed under the terms of the Creative Commons Attribution License (CC BY). The use, distribution or reproduction in other forums is permitted, provided the original author(s) and the copyright owner(s) are credited and that the original publication in this journal is cited, in accordance with accepted academic practice. No use, distribution or reproduction is permitted which does not comply with these terms. 